Primljen / Received: 13.7.2012.

Ispravljen / Corrected: 8.10.2012.

Prihvaćen / Accepted: 19.10.2012.

Dostupno online / Available online: 15.11.2012.

\section{Properties of asphalt concrete at low temperatures}

\section{Authors:}

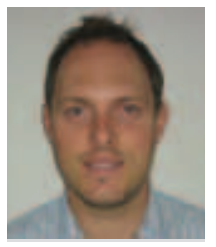

Dejan Hribar, MSc. CE

Construction Institute ZRMK d.o.o.

Center for Transportation and Infrastructure dejan.hribar@gi-zrmk.si

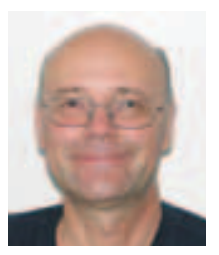

Asst.Prof. Marjan Tušar, PhD. Ch.E.

Chemical Institute of Ljubljana

marjan.tusar@ki.si

\section{Dejan Hribar, Marjan Tušar}

Professional paper

\section{Properties of asphalt concrete at low temperatures}

The testing of asphalt mixes to be used in wearing courses of pavement structures are presented in the paper. Asphalt concrete mixes AC 11 are tested at low temperatures. Two testing procedures are conducted: testing by cooling and uniaxial tensile testing. The analysis of results has shown better correlation of bitumen mix properties and uniaxial tensile testing results, when compared to bitumen mix properties and testing by cooling. The testing has revealed that significant improvement of asphalt concrete properties, and its higher resistance to low-temperature cracking, is obtained if the mass percent of bitumen is increased to more than 4.8 percent.

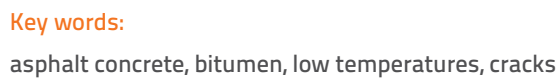

Stručni rad

Dejan Hribar, Marjan Tušar

\section{Svojstva asfaltbetona pri niskim temperaturama}

U radu su prikazana ispitivanja provedena na uzorcima izrađenim od asfaltbetona AC 11 pri niskim temperaturama, koji su prikazani kao funkcije sastava asfaltne mješavine. Analiziraju se dva postupka ispitivanja i to postupak hlađenjem te jednoosno vlačno ispitivanje. Analiza rezultata je pokazala bolju korelaciju između svojstava bitumenskih mješavina i rezultata jednoosnog vlačnog ispitivanja nego između svojstava bitumenskih mješavina i ispitivanja hlađenjem. Uočena je dobra korelacija između rezultata kod maksimalnih rezervi vlačne čvrstoće i temperature pri maksimalnoj rezervi vlačne čvrstoće, kao funkcija udjela bitumena, šupljina, zbijenosti, šupljina ispunjenih bitumenom i Marshallova stabiliteta.

Ključne riječi:

asfaltbeton, bitumen, niske temperature, pukotine

Fachbericht

Dejan Hribar, Marjan Tušar

\section{Eigenschaften von Asphaltbeton bei niedrigen Temperaturen}

In der Arbeit werden Untersuchungen von Asphaltmischungen für die Verschleißschichten von Fahrbahnkonstruktionen dargestellt. Untersucht werden Mischungen des Asphaltbetons AC 11 bei niedrigen Temperaturen. Es wurden zwei Untersuchungsverfahren angewendet: durch Kühlung und eine einachsige Zuguntersuchung. Die Analyse der Resultate zeigte eine bessere Korrelation zwischen den Eigenschaften von Bitumenmischungen und den Resultaten der einachsigen Zuguntersuchung als zwischen den Eigenschaften der Bitumenmischungen und der Untersuchung mit dem Kühlungsverfahren. Mithilfe der durchgeführten Untersuchungen wurde festgestellt, dass es durch Erhöhung des Massenanteils an Bitumen auf über 4,8\% zu erheblichen Verbesserungen der Eigenschaften des Asphaltbetons und zur Erhöhung seiner Rissfestigkeit bei niedrigen Temperaturen kommt.

Schlüsselwörter:

Asphaltbeton, Bitumen, niedrige Temperaturen, Risse 


\section{Introduction}

In nature, most substances including asphalt extend when heated and contract when cooled. If the contraction due to cooling is prevented with falling temperatures, the tensile stress in the asphalt material will increase, which can lead to fracture if the maximum tensile strength is reached [1]. The low temperature cracking occurs as transverse (cryogenic stress) and/or longitudinal (low temperature and traffic loading), and it propagates down from the surface.

Results obtained by the analysis and testing of the asphalt concrete 11 surf B50/70 A2/Z2 at low temperatures, as a function of asphalt mixture properties, are presented in the paper. The Tensile Stress Restrained Specimen Test TSRST, and the Uniaxial Tensile Strength Test - UTST, were conducted according to EN 12697-46 [2]. The TSRST test (Figure 1a) simulates the condition of asphalt pavement at low temperatures, where the resulting thermally induced tensile stresses, called cryogenic stress, primarily reflect as transverse cracks spaced at 3 to $5 \mathrm{~m}$ intervals (Figure 1b). The UTST test (Figure 2a) simulates the resistance of low-temperature asphalt mixtures exposed to traffic loading. The maximum critical tensile stress does not occur in the wheel track but at the distance of $30 \mathrm{~cm}$ to $90 \mathrm{~cm}$ away from the location of the load (Figure 2b) [3]. The difference between the tensile strength and the low temperature stress is known as the tensile strength reserve $\Delta \beta(T)$ and it is the reserve that is available for accommodating additional superimposed stresses (traffic inducted stress) [4]. An example of the tensile strength reserve evaluation based on TSRST and UTST test results is given in Figure 3. The analysis of results has shown a better correlation between the properties of bituminous mixtures and UTST test results, than between the properties of bituminous mixtures and the TSRST test. What is especially visible is a good correlation between the results in the maximum reserves of tensile strength and temperature at the maximum tensile strength reserve as a function of bitumen content, air voids, bulk density, voids filled with bitumen (VFB) and Marshall stiffness.
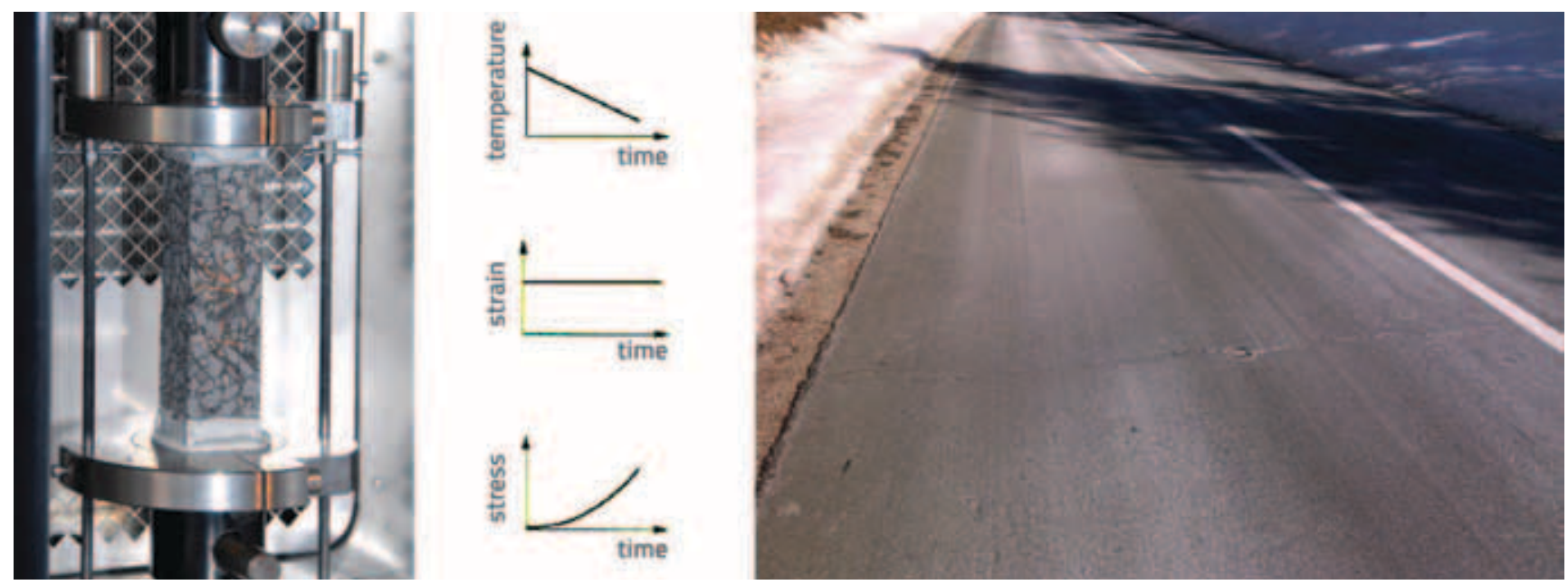

Figure 1. a) Tensile Stress Restrained Specimen Test - TSRST; b) Transverse thermal crack (Babno Polje, February 2012)
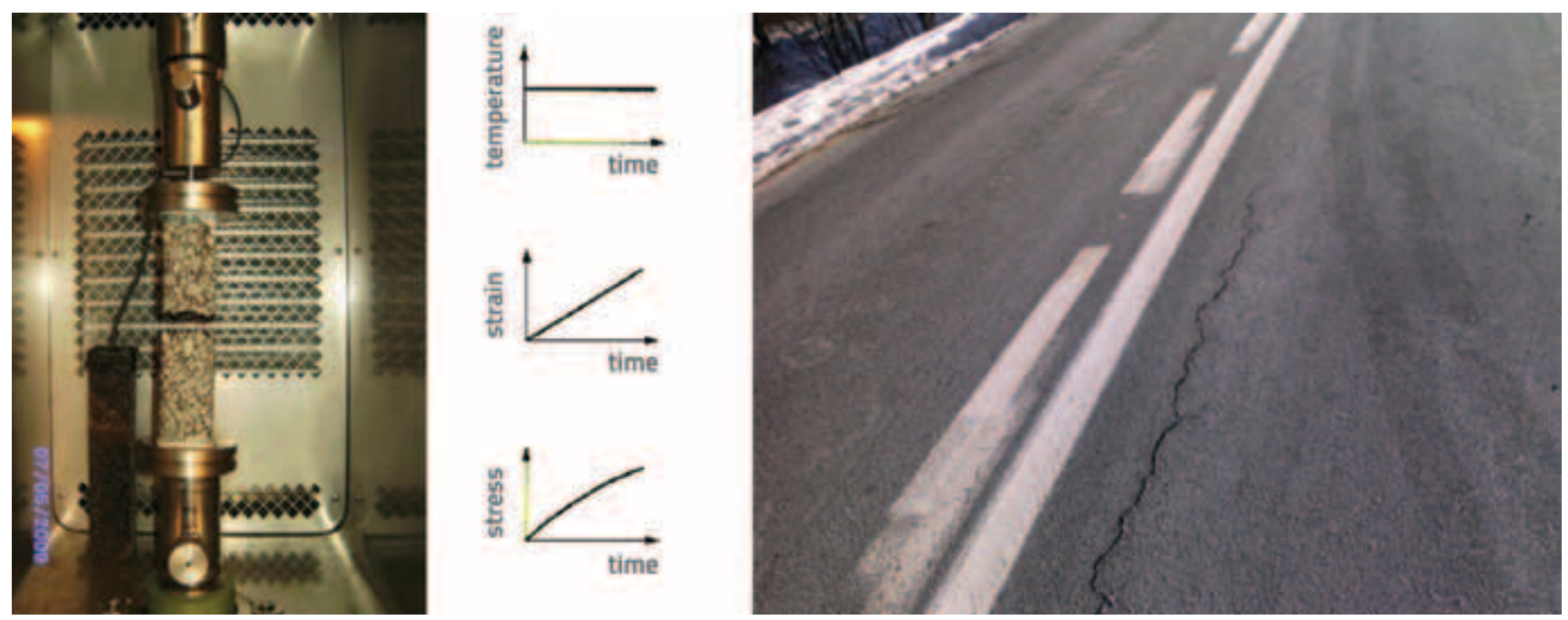

Figure 2. a) Uniaxial Tensile Strength Test - UTST; b) Longitudinal crack at the wheel tracks (Babno Polje, February 2012) 


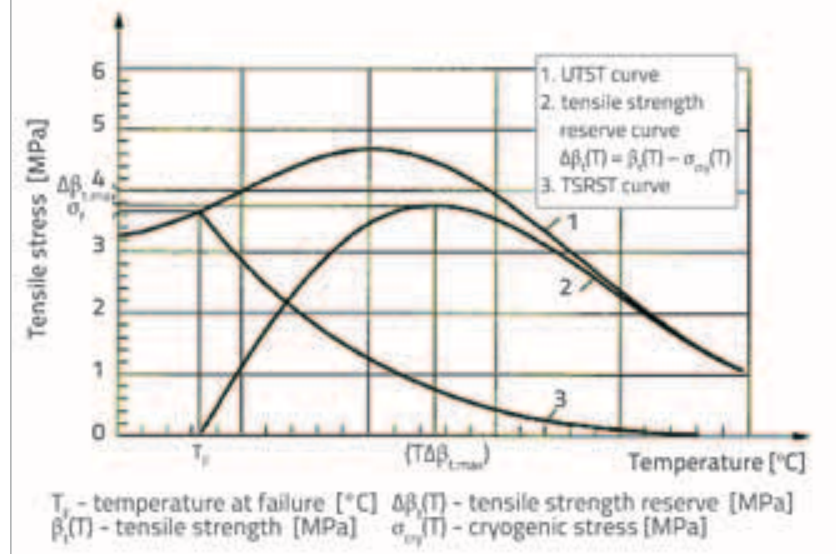

Figure 3. Schematic curves for the TSRST test, UTST test, and tensile strength reserve [2]

\section{Testing asphalt concrete mixtures at low temperatures}

\subsection{Material}

The tests were carried out on asphalt concrete $A C 11$ surf $B 50 / 70 A 2 / Z 2$ in the laboratory of the Slovenian National Building and Civil Engineering Institute (ZAG). A rectangular specimen measuring $40 \times 40 \mathrm{~mm}$ in diameter, and $160 \mathrm{~mm}$ in length, was used. The asphalt mixtures were prepared in the laboratory according to the asphalt producer's mixture design no. CGP 06-2009. The following stone fractions were used for the stone aggregate mixture: filler aggregate $(<0.125$ $\mathrm{mm}$ ) from Stahovica (limestone), mineral aggregate 0/2, 2/4, 4/8, and 8/11 mm from Ljubešćica (silicate), while the paving grade bitumen $\mathrm{B} 50 / 70$ by MOL (Hungary) was used as binder. Five different mixtures with bitumen content of 4.0, 5.0, 5.4, 5.8 and 6.0 mass \%. were prepared in laboratory. Properties of fresh and extracted paving grade bitumen B50/70 are shown in Table 1. The grain size distribution for each mixture, as related to bitumen content, is presented in Figure 4 . It can be noted that the grain size distributions overlap, while the filler aggregate is practically constant.

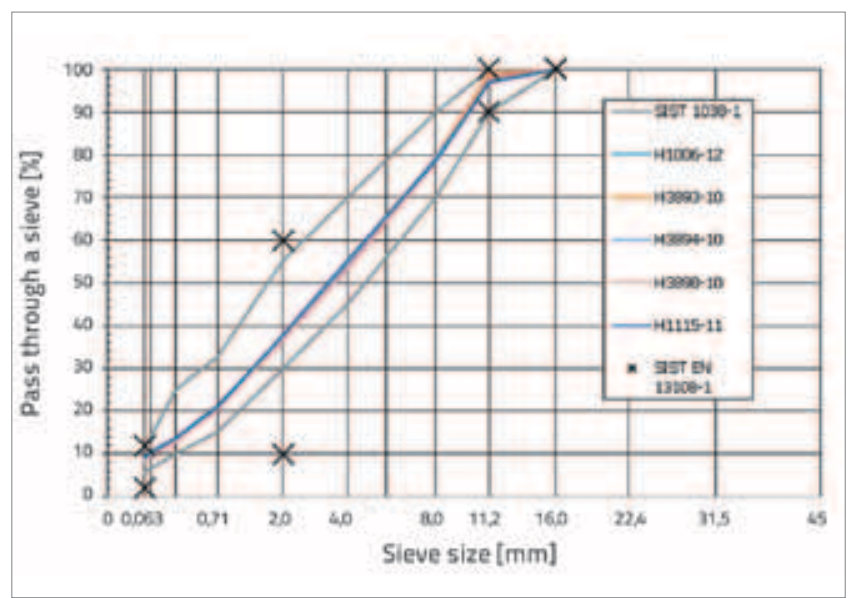

Figure 4. Grain size distribution of stone aggregate $0 / 11 \mathrm{~mm}$.

Table 1. Properties of paving grade bitumen B50/70

\begin{tabular}{|c|c|c|c|c|}
\hline Technical characteristics & Unit & Test method & Fresh bitumen & Extracted bitumen \\
\hline Penetration at $25{ }^{\circ} \mathrm{C}$ & $\mathrm{mm} / 10$ & SIST EN 1426:2007 & 56 & 39 \\
\hline Softening point, R\&B & ${ }^{\circ} \mathrm{C}$ & SIST EN 1427:2007 & 52 & $-0,4$ \\
\hline Penetration Index, $\mathrm{PI}$ & - & SIST EN 12591:2004, klauzula B4 & -15 & $-0,25$ \\
\hline Fraass braking point & ${ }^{\circ} \mathrm{C}$ & SIST EN 12593:2007 & 1014.2 & -13 \\
\hline Density (in water) & $\mathrm{kg} / \mathrm{m}^{3}$ & SIST EN ISO 3838 & - \\
\hline
\end{tabular}

Table 2. Results of some basic asphalt mixture tests

\begin{tabular}{|c|c|c|c|c|c|c|}
\hline $\begin{array}{c}\text { Mark } \\
\text { of performed } \\
\text { testing }\end{array}$ & $\begin{array}{c}\text { Bitumen content } \\
{[\text { mass } \%]}\end{array}$ & $\begin{array}{c}\text { Grain size } \\
<0.063 \mathrm{~mm} \\
{[\text { mass } \%]}\end{array}$ & $\begin{array}{c}\text { Bulk density } \\
\text { of Marshall } \\
\text { specimen } \\
{[\mathrm{kg} / \mathrm{m} \text { 3] }}\end{array}$ & $\begin{array}{c}\text { Air voids } \\
\text { of Marshall } \\
\text { specimen } \\
{[\text { volum \%] }}\end{array}$ & $\begin{array}{c}\text { Voids filled with } \\
\text { bitumen } \\
{[\text { volum \%] }}\end{array}$ & $\begin{array}{c}\text { Marshall stiffness } \\
{[\mathrm{kN} / \mathrm{mm}]}\end{array}$ \\
\hline H1006-12 & 3.9 & 9.3 & 2404 & 8.0 & 62.8 & 2.7 \\
\hline H3893 & 4.9 & 9.1 & 2441 & 5.0 & 79.4 & 2.3 \\
\hline H3874 & 5.3 & 9.0 & 2461 & 3.8 & 86.1 & 2.1 \\
\hline H3898 & 5.6 & 8.6 & 2467 & 2.6 & 92.5 & 2.7 \\
\hline H1115-11 & 6.0 & 9.0 & 2484 & 1.8 & 97.9 & 1.8 \\
\hline
\end{tabular}


When the content of bitumen at the same stone aggregates sieving curve is varied, then the content of air voids or the content of filler aggregate must be alternated. In our research, we decided to try to keep a constant content of filler aggregate in asphalt mixture, and to vary air voids. The results of some basic asphalt mixture tests are presented in Table 2. However, the results show that we slightly varied the filler content. The maximum deviation from the target filler content was found in the asphalt with the bitumen content of 5.6 mass $\%$.

\section{Results and analysis}

Results obtained by the cooling test (TSRST) for the asphalt mixture AC 11 surf B 50/70 A2/Z2 show a poor correlation between the tensile stress $\sigma_{\mathrm{f}} /$ bitumen content and the fracture temperature $T_{f} /$ bitumen content. Correlation coefficient values are $\mathrm{R}^{2}=0.35$ and $\mathrm{R}^{2}=0.55$ (Figure 5). On the other hand, uniaxial tensile test (UTST) results show surprisingly good correlations between maximum tensile strength reserve $\Delta \beta$ / bitumen content $\left(R^{2}=0.92\right)$, and the temperature at maximum tensile strength reserve $T_{\Delta \beta}$ / bitumen content $\left(R^{2}=0.90\right)$ (Figure 6). It can be concluded from these correlations that the UTST test better describes the influence of bitumen content at low temperatures. In addition, the variation of filler content (Table 2) has a greater effect on the cooling test (TSRST) results. It can be seen from Figure 6 a that, with an increase of bitumen content from 4.8 to 6.0 mass \%, the maximum tensile strength reserve $\Delta \beta$ increases significantly, and the temperature at the maximum tensile strength reserve $T_{\Delta \beta}$ reduces drastically from $-6.7{ }^{\circ} \mathrm{C}$ to $-10.5^{\circ} \mathrm{C}$ (Figure 6b). Both values slightly change for asphalt mixtures with bitumen content between 4.0 and 4.8 mass \%. It can be concluded from these results that the
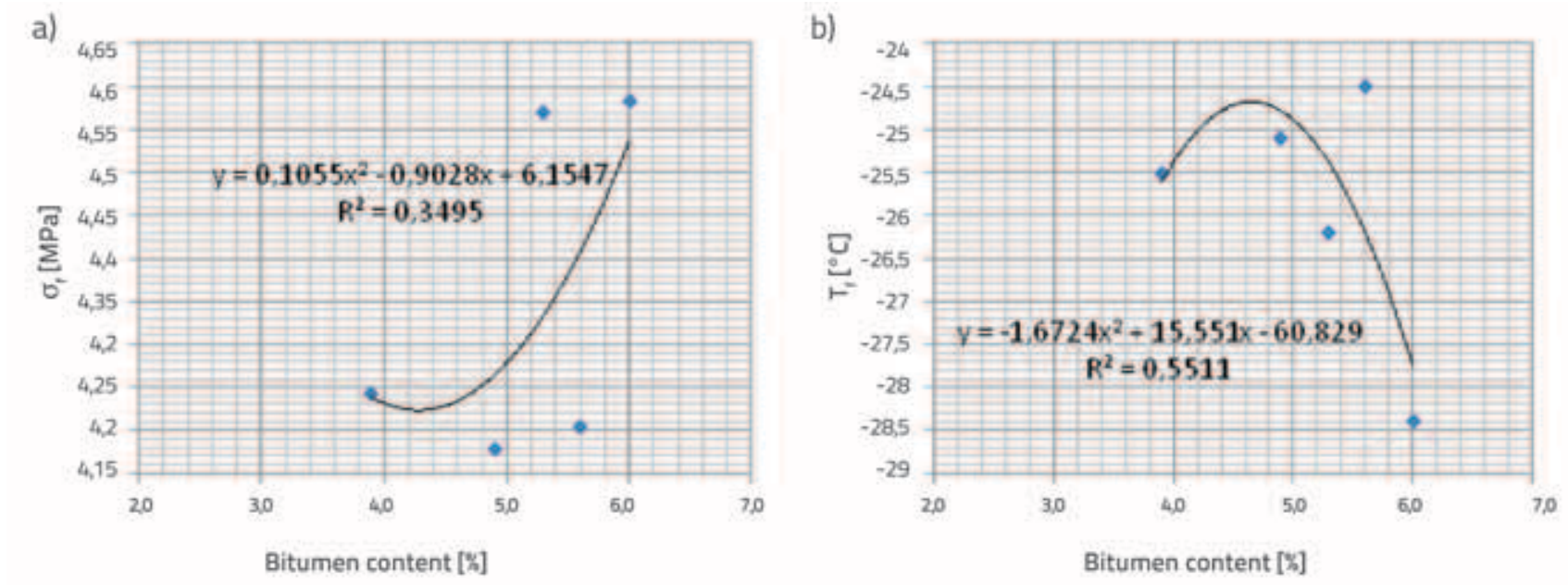

Figure 5. Results of cooling test TSRST for AC 11 surf B 50/70 A2/Z2 as related to bitumen content B [mass \%]: a) Maximum tensile stress $\sigma_{f i}$ b) Fracture temperature
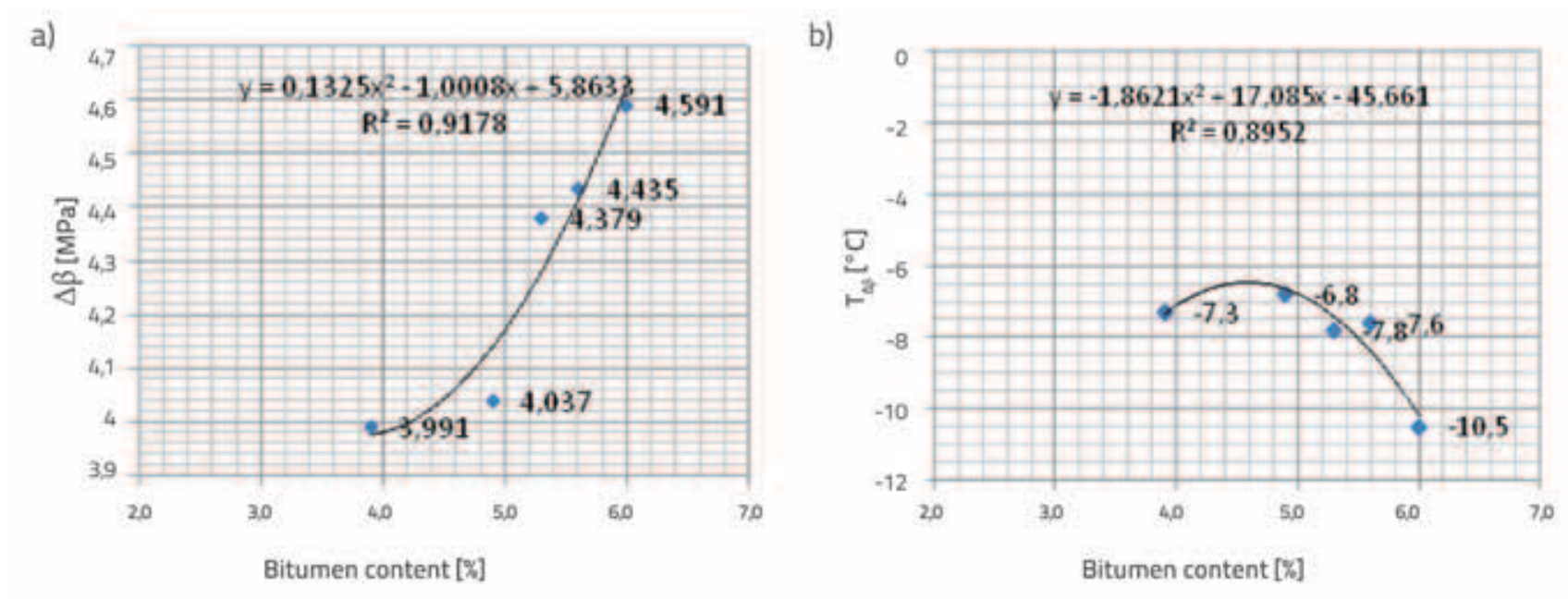

Figure 6. a) Maximum tensile strength reserve $\Delta \beta$ as related to bitumen content $B$ [mass \%]; b) Temperature at maximum tensile strength reserve $T_{\Delta \beta}$ as related to bitumen content $B$ [mass \%] 

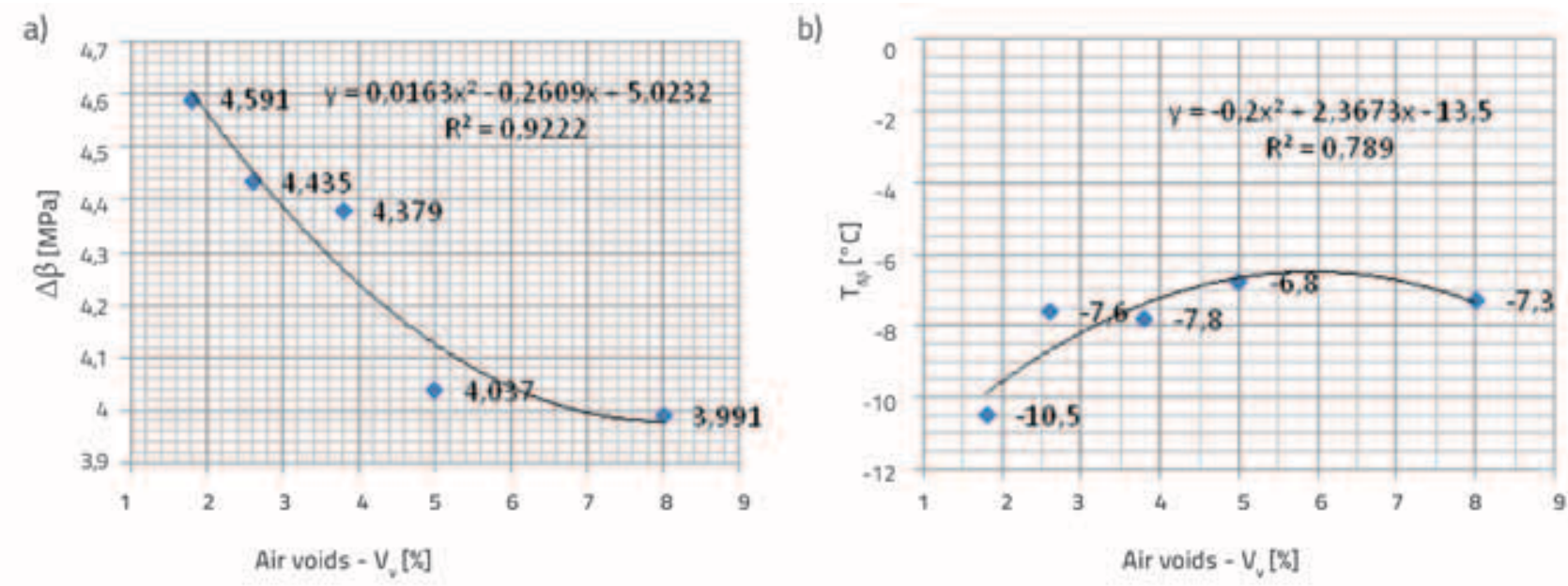

Figure 7. a) Maximum tensile strength reserve $\Delta \beta$ as related to air voids $V_{v}$ i b) Temperature at the maximum tensile strength reserve $T_{\Delta \beta}$ as related to air voids $\mathrm{V}_{\mathrm{v}}$
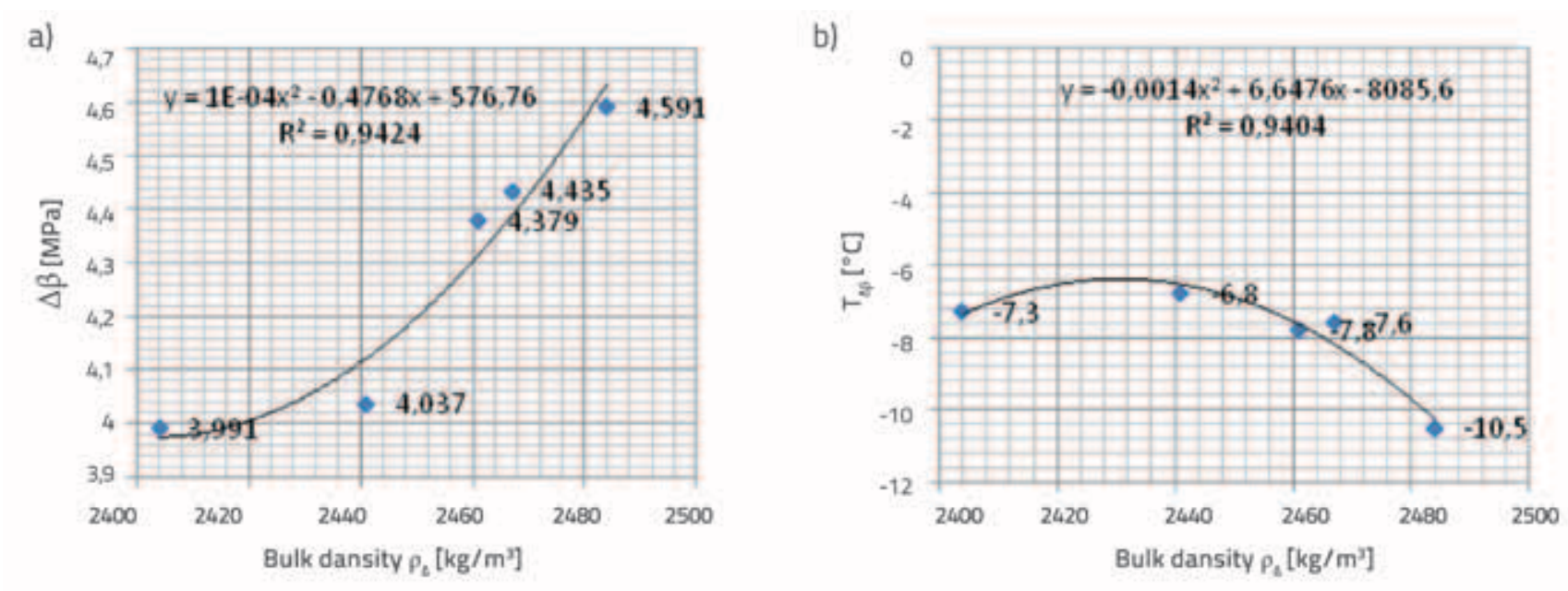

Figure 8. a) Maximum tensile strength reserve $\Delta \beta$ as related to bulk density; b) Temperature at the maximum tensile strength reserve $T_{\Delta \beta}$ as related to bulk density $T_{\Delta \beta}$

role of bitumen content is significant at low temperatures. The increase in bitumen content above 4.8 mass $\%$ results in significant improvement of the studied asphalt concrete properties, and in an increased resistance to cracking at low temperatures.

In this research, the bitumen content, and hence the air voids content in asphalt mixture, was modified, while the filler content remained constant. The unintentional variation of filler content resulted in an incomplete correlation between the bitumen content and air voids $\left(R^{2}=0.996\right)$. Consequently, the correlations between bitumen content with voids filled with bitumen VFB $\left(R^{2}=0.997\right)$ and bulk density $\left(R^{2}=0.995\right)$ are much higher. Since a poor correlation between TSRST and volumetric properties of bituminous mixtures was established, only the results of test UTST are presented in this paper. A good correlation between the UTST test and air voids $V_{v}$ [volum
$\%$ is presented in Figure 7. A decrease in the air voids content, under the 5.0 volum $\%$, resulted in a significant increase in tensile strength reserve $\Delta \beta$ and reduction of temperature at the maximum tensile strength reserve $T_{\Delta \beta}$. The temperature was reduced from $-6.5^{\circ} \mathrm{C}$ to $-8.2^{\circ} \mathrm{C}$. It is well known that the higher the bitumen content in the asphalt mixture the lower the voids content. The dependence between the uniaxial tensile test (UTST) results and bulk density $\rho_{A}$ is shown in Figure 8 . The correlation is relatively good $R^{2}=0.94$. Even in this case we can see that by increasing the density, we increase the maximum tensile strength reserve $\Delta \beta$, and decrease the temperature at the maximum tensile strength reserve $T_{\Delta \beta}$. It can be concluded that air voids and bulk density are closely related to the bituminous mixture properties at low temperatures.

A good correlation between the results at maximum tensile strength reserve $\Delta \beta$ and voids filled with bitumen VFB is 

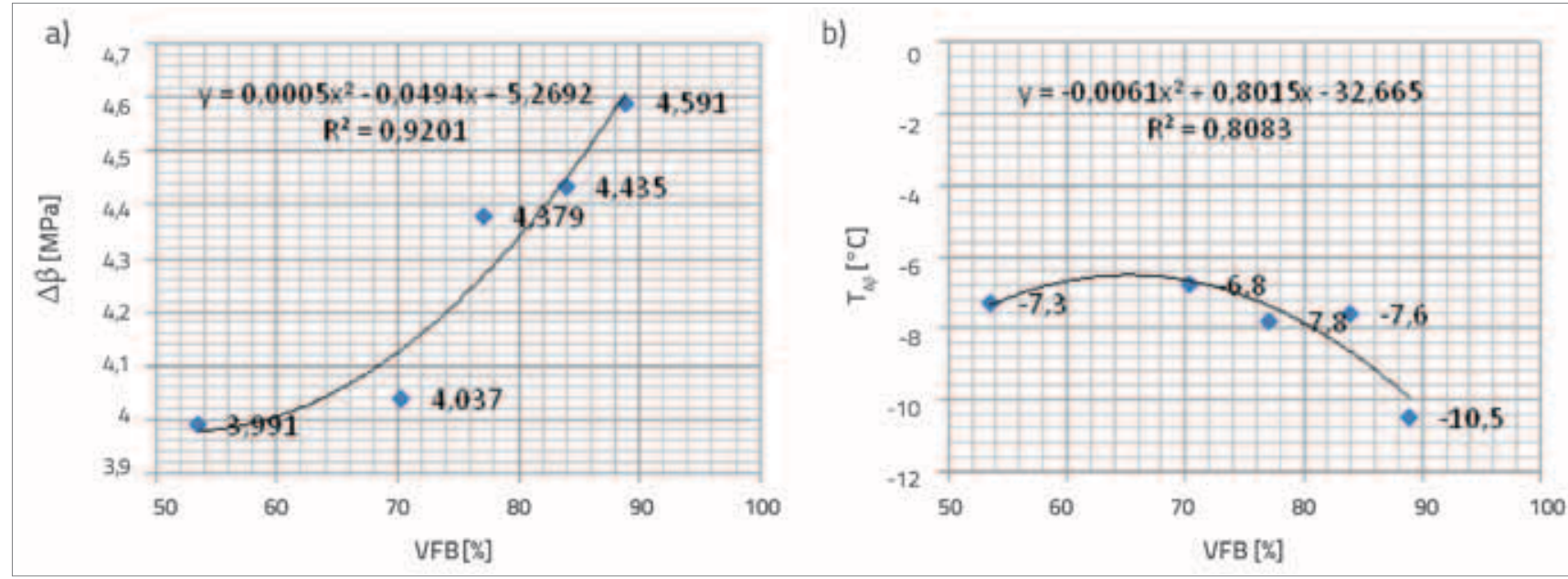

Figure 9. a) Maximum tensile strength reserve $\Delta \beta$ as related to voids filled with bitumen VFB; b) Temperature at the maximum tensile strength reserve $T_{\Delta \beta}$ as related to voids filled with bitumen VFB
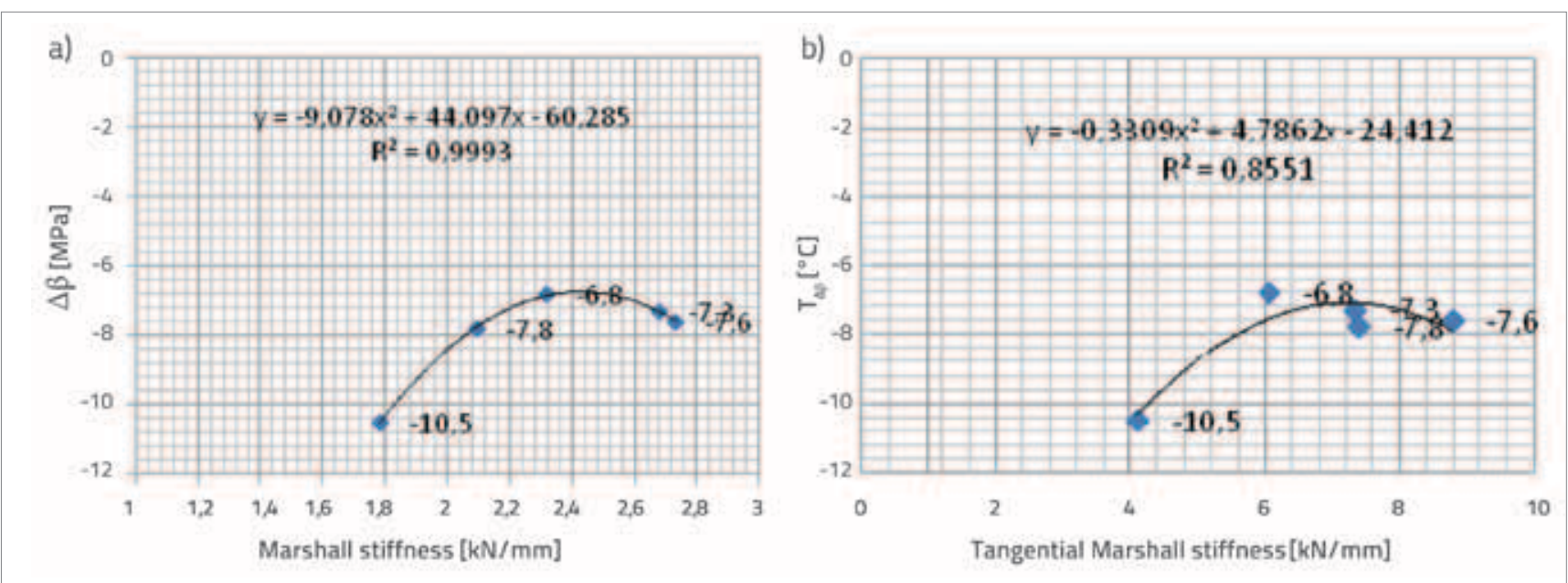

Figure 10. a) Temperature at the maximum tensile strength reserve $T_{\Delta \beta}$ as related to the Marshall stiffness; b) Temperature at the maximum tensile strength reserve $T_{\Delta \beta}$ as related to the tangential Marshall stiffness

presented in Figure 7. It was established that, with higher VFB, a higher maximum tensile strength reserve $\Delta \beta$, and a lower temperature at the maximum tensile strength reserve $T_{\Delta \beta_{1}}$ can be expected. It can be seen in Figure 10a that the polynomial regression curve shows a surprisingly good correlation $\left(\mathrm{R}^{2}\right.$ $=0.999$ ) between the temperature at the maximum tensile strength reserve $T_{\Delta \beta}$ and the Marshall stiffness. The Marshall stiffness value at the maximum of the polynomial regression curve is $2.4 \mathrm{kN} / \mathrm{mm}$, while the temperature at the maximum tensile strength reserve $T_{\Delta \beta}$ is $-6.8^{\circ} \mathrm{C}$. This result could be explained by the fact that the stiffness of asphalt mixtures is in good correlation with the linear combination of bitumen and filler content $\left(R^{2}=0.97\right)$. The correlation of the Marshall tangential stiffness and the temperature at the maximum tensile strength reserve $T_{\Delta \beta}$ (Figure 10b) is relatively good $\left(R^{2}=\right.$ 0.855), although it is lower than in case of the normal Marshall stiffness.

\section{Conclusion}

Results obtained by testing the asphalt concrete type $A C 11$ surf B 50/70 A2/Z2 at low temperatures, as a function of volumetric properties of the mixture, are presented in this paper. The cooling test (Tensile Stress Restrained Specimen Test - TSRST) and the uniaxial tensile test (Uniaxial Tensile Strength Test - UTST) were conducted. The analysis of results has shown a better correlation between the properties of bituminous mixtures and UTST test results, than between the properties of bituminous mixtures and the TSRST test. Due to a limited number of samples, it is not clear whether this phenomenon is due to a testing error, or perhaps it points to a more general occurrence. A good correlation has been noted between the results in the maximum reserves of tensile strength and temperature at the maximum reserve tensile strength, as a function of 
bitumen content, air voids, bulk density, voids filled with bitumen (VFB), and Marshall stiffness. Based on these correlations, it was concluded that the influence of bitumen content at low temperatures is better described with the UTST test. In addition, the variation in filler content exerts

\section{LITERATURA}

[1] Arand, W.: On the creck resistance and the fatigue behaviour of asphalts for pavements, Institut für Strassenwesen, Braunschweig, 7. kolokvij o bitumnih, Združenje asfalterjev Slovenije, Gozd Martuljek; 2002, p. 3-15.

[2] kSIST FprEN 12697-46:2011: Bituminous mixtures - Test methods for hot mix asphalt - Part 46: Low temperature cracking and properties by uniaxial tension tests, 2011. a greater influence on the cooling test (TSRST) results. It was established that a significant improvement in asphalt concrete properties, and an increased resistance to cracking at low temperatures, is obtained by increasing the bitumen content to more than 4.8 mass $\%$.

[3] Spiegl, M.:Tieftemperaturverhalten von bituminösen Baustoffen - Labortechnische Ansprache und numerische Simulation des Gebrauchsverhaltens. Dissertation, Institut für Straßenbau und Straßenerhaltung, Technische Universität Wien, Heft 19,Wien, 2008, p. 13-17

[4] The Shell Bitumen Handbook, 5th edition, Tomas Telford Publishing, London, 2003, p. 196-199. 